\title{
Intergenerational Justice and Institutions for the Long Term
}

\author{
Iñigo González-Ricoy
}

Forthcoming in The Oxford Handbook of Time and Politics, Klaus Goetz, ed. (New York: Oxford University Press).

Abstract: Institutions to address short-termism in public policymaking and to more suitably discharge our duties toward future generations have elicited much recent normative research, which this chapter surveys. It focuses on two prominent institutions: insulating devices, which seek to mitigate short-termist electoral pressures by transferring authority away to independent bodies, and constraining devices, which seek to bind elected officials to intergenerationally fair rules from which deviation is costly. The chapter first discusses sufficientarian, egalitarian, and prioritarian theories of our duties toward future generations, and how an excessive focus on the short term in policymaking may hinder that such duties be fulfilled. It then surveys constraining and insulating devices, and inspects their effectiveness to address the epistemic, motivational, and institutional drivers of political short-termism as well as their intra- and intergenerational legitimacy.

Keywords: future generations, institutional design, short-termism, intergenerational justice, legitimacy.

Some of our most pressing policy choices involve thorny intertemporal dilemmas. To produce a skilled workforce, mitigate climate change, prepare for disasters, or keep public debt sustainable, governments have to take costly action today (e.g., raise taxes, cut benefits, impose regulations) with benefits arriving in the long run. Given the risks involved, electoral and otherwise, politicians have strong incentives to privilege policies with more immediate returns and to renege prior long-term commitments in such policy areas, rolling over the costs of inaction to future generations (Nordhaus 1975; Thompson 2010). An unusually blunt statement from the former director of the Spanish Budgetary Office, Álvaro Nadal, is a case in point. "We should reduce investment in research and development," he argued to explain cutbacks in research, "as they are no profitable option in the short term" (Expansión, 2015).

To address short-termism in public policymaking and to more suitably discharge our duties toward future generations, numerous institutional reforms have been proposed and attempted in recent decades (United Nations Secretary-General, 2013; Oxford Martin Commission for Future Generations, 2013; González-Ricoy and Gosseries, 2016a; Boston 2017; Caney, 2019). This chapter focuses on two prominent kinds: insulating and constraining devices (Brunner, et al., 2012; Jacobs and Matthews, 2017). Insulating devices, such as independent agencies and watchdogs, aim at shielding policymaking from short-termist pressures by transferring authority away from elected officials. Constraining 
devices, by contrast, seek to bind elected officials to certain intertemporally appropriate rules from which deviation is costly. They comprise hypothecated taxes, trust funds, and constitutional principles of intergenerational fairness, which many countries have adopted and courts in the Philippines, Chile, or the Netherlands have enforced.

Insofar as these and similar institutions can be intentionally designed, questions about their effectiveness and legitimacy arise, which much recent normative research has tackled and this chapter inspects. Section 1 discusses sufficientarian, egalitarian, and prioritarian theories of our duties toward future generations and when a focus on the short term in public policymaking may infringe them. Section 2 surveys future-beneficial and futurefocused institutions and, among these, constraining and insulating devices. Section 3 presents two criteria to assess such devices: their effectiveness to address the epistemic, motivational, and institutional sources of short-termism and their legitimacy in allocating power, intra- and intergenerationally. Section 4 discusses how well constraining and insulating devices fare as to these criteria. Although constraining devices are generally better equipped to satisfy them, I argue, insulating devices may be suitably designed to address some of their shortcomings. Section 5 concludes by discussing some areas for future research.

\section{Wrongful short-termism and intergenerational justice}

Many of our policy choices today will importantly affect future generations - a category that comprises two distinct groups: those who, like children, are not yet citizens and those who are not yet born. Some policy choices, such as the amount of public debt we accumulate or how much we invest in early education, will affect the former. Some others, like nuclear waste management or climate change policies, will have much longer life spans, also affecting generations yet unborn. Both kinds of policy choices, however, involve tradeoffs between immediate and future benefits, and are likewise liable to shorttermist pressures in public policymaking. For elected officials have strong incentives to privilege policies with payoffs arriving before the next election and to renege prior farsighted commitments that may be optimal in the long term yet not in the short run. No wonder many, like Kevin Rudd, former Prime Minister of Australia, refer to short-termism as "the virus, the disease, some would say the epidemic [that] threatens [our] long-term future" (Gallery and Gallery, 2009: 275).

Yet privileging the short term need not always be wrongful. If, for example, we can safely expect future generations to be wealthier than us, then passing greater financial burdens on to them may be justified due to diminishing marginal utility or to a distributive principle that puts the worst off first (Price, 2003). And discounting the value of future benefits in public policymaking may also be permissible to account for the profitable investment opportunities that are foregone (Broome, 1994).

What, then, makes short-termism wrongful? First, there are cases in which an

excessive focus on the short run may yield an inefficient allocation of burdens and benefits 
across time and generations. For example, Heckman, et al. (2010) suggest that investing \$1 on preschool education targeted at disadvantaged African-American youth yields $\$ 12,2$ in long-term social gains, after discounting such gains at 5 percent per annum. And the immediate imposition of a carbon tax of $\$ 27$ per ton, rising to $\$ 90$ per ton by 2050 , would pay for itself over the long run in avoided losses to GDP, after discounting future benefits at 4 percent per annum, Nordhaus (2008) argues. Failing to act in these cases because shortterm gains are privileged, brings about, other things equal, inefficient outcomes.

A second kind of wrongful short-termism, which often overlaps with the first, occurs when present policies infringe our duties toward future generations, which failing to invest in early education or leaving climate change unabated, for example, would prima facie do. We need, however, a full normative account of such duties. For ascertaining when exactly, and to what extent, privileging present interests over future ones is wrongful in this second sense will depend on the particular obligations toward future generations we have.

\subsection{Theories of intergenerational justice}

Theories of intergenerational justice address our duties to both past and future generations. We here focus on the latter, whose content has prompted two kinds of questions. One, which we sidestep here, is whether anything is owed to individuals who do not yet exist, whose identity is contingent on our present decisions, and with whom cooperation is unfeasible. Assume, however, that responses to these challenges are successful (for overviews, see Kumar, 2018; Meijers, 2018; Caney, 2018). A second, more relevant question for the issue at hand is what is owed, rather than whether anything is owed, to future generations. We need to ask, then, what the content of our duties to future generations is. A question sufficientarian, egalitarian, and prioritarian theories approach differently.

Start with intergenerational sufficientarianism, according to which the duty each generation has toward subsequent generations is that of leaving conditions that allow a minimum threshold of living (Meyer and Roser, 2009; Gosseries, 2017). The view, which is most famously expressed by the Brundtland Commission's definition of sustainable development as "development that meets the needs of the present without compromising the ability of future generations to meet their own needs" (World Commission on Environment and Development, 1987: 43), has various distinctive features. One is that our duty to leave enough for the future is largely independent from what we may end up having as a result of choice and circumstance, including what we inherit from past generations. ${ }^{1}$ Another is that what counts as enough is typically defined, on this view, by reference to an objective standard, like basic needs or capabilities, rather than to future generations' preferences-whose content is harder to foresee, especially as to distant generations, and

\footnotetext{
${ }^{1}$ This contrasts with theories, whose discussion space limits forbid, that define what each cohort owes to subsequent cohorts in accordance to what they receive from past cohorts (e.g., Mulgan, 2006).
} 
more contingent on prior generations' own preferences through formal and informal education (Ekeli, 2007; Gosseries, 2017).

One complication is how to define, and where to set, the relevant threshold. Rawls' (1999: 159) "institutional sufficientarianism," for example, holds that we have a duty to bequeath the conditions "needed to establish and to preserve a just basic structure over time." Many, however, favor less taxing (and more specific) definitions of the threshold, like avoiding deprivation or meeting basic needs. But most would agree that, albeit hard to specify, sufficiency is a necessary element of what we owe to future generations. Is it also enough, however? Some think not (Casal, 2007; Caney, 2018). For, suppose we could greatly benefit later cohorts above the threshold or redress gross intergenerational inequalities at little or no cost to ourselves. It seems clear that we would then have a duty to do so, and that privileging the short term instead would be wrongful. A second, more demanding view involves, thus, a requirement to equalize generations by benefiting those who are worse off. A view that comes in roughly two forms: relational and distributive.

Relational egalitarianism holds that what we should seek to equalize is not how benefits are distributed across generations but how generations relate to one another, such that all generations be treated as equals by preceding cohorts and relations of exploitation (Liberto, 2014) or domination (Katz, 2017) be avoided. The view may be apt for relations among overlapping generations (Bidadanure, 2016a). But it is less so, many argue, for intergenerational relations beyond the overlap (Caney, 2018). For the kind of exploitative or dominating relations this view seeks to root out typically require interaction between a perpetrator and a victim, which is only possible among contemporaries. Failing to abate climate change due to an excessive focus on the short term may, then, wrong future people. But it is unclear whether it also involves exploiting or dominating them.

Distributive egalitarianism, by contrast, seeks to equalize the allocation of morally relevant benefits - welfare, resources, or capabilities, to name some prominent candidates of the metric that, according to different proponents of this view, we should primarily use. On a strict variant, intergenerational egalitarianism is indifferent to the absolute level of benefits members of each generation enjoy. It is thus liable to the so-called leveling down objection: it could recommend, if growing prosperity is expected, that better-off generations' position be worsened for the sake of equality, whose value is deemed intrinsic.

On a prioritarian variant, by contrast, what matters is not equality per se but benefitting those who are worst-off (Parfit, 1997). And doing so matters more the worse off the worst-off are. Prioritarianism has, in brief, an intrinsic tendency toward equality. For between two cohorts whose prospects are uneven it favors that the position of the worse off cohort be enhanced-which has led some, like Fleurbaey (2015), to argue that prioritarianism and strict egalitarianism largely overlap as to their practical recommendations. But it does not value equality as such, and thus avoids the leveling down objection.

When applied to nonoverlapping generations, however, egalitarianism is liable to important concerns (Meyer and Roser, 2009; Casal, 2019). First, to justify it, we cannot 
resort to many of the instrumental reasons to denounce inequality among contemporaries, such as its effects on crime, distrust, physical and mental illness, teenage pregnancy, drug use, obesity, or pollution - effects that inequality among distant cohorts may not yield. Nor can we resort to intrinsic condemnations of inequality, which may not be objectionable across distant cohorts. Second, pursuing intergenerational equality (or priority) across distant generations would impose overwhelming computational burdens. How can we ascertain what would make future people, whose preferences and conditions are likely to radically differ from ours, neither worse off nor better off than us? Finally, intergenerational equality would be awfully hard to realize, given the vast institutional apparatus needed to achieve it and the inescapable power asymmetry between present and later generations.

Egalitarianism is, in brief, apt to define our duties toward younger cohorts but not toward those yet to come, for which sufficientarianism is better suited. For example, given that sufficientarianism is concerned with the absolute position of future generations, it can be justified with no reference to the intrinsic or instrumental worth of their position relative to that of past or subsequent cohorts. And it is also informationally less exacting and easier to politically realize, given that it is merely concerned with avoiding that anyone falls below certain minimal threshold - one that, in addition, is defined in preference-insensitive terms, like avoiding deprivation or protecting basic needs.

When, and to what extent, short-termism in policymaking is wrongful will hinge, then, on two things. The first is the time horizon of the relevant policy choice: whether it is likely to only affect those who, like children, are not yet citizens, to whom equality is owed, or will also affect those who are not yet born, to whom sufficiency is owed. The second is whether privileging the short term would infringe the duties we may then have for that particular policy choice.

\section{Future-beneficial and future-focused institutions}

Let us now consider institutional responses to wrongful short-termism. It is commonplace to view such responses as a means to correct democracies' built-in bias toward the present. On a popular view, shared by scholars and citizens alike, electoral cycles, voters' myopia, and incumbents' desire to remain in office inexorably yield policies that privilege immediate benefits over future payoffs (Nordhaus, 1975; Thompson, 2010). Yet, although electoral pressures toward the short term are no doubt daunting, the record of existing democracies offers a more complicated picture. Democratic governments display an ample range of intertemporal choices: they greatly vary as to how much public debt they amass, how much they invest in education, or how well they preserve their forests (Jacobs, 2011; MacKenzie, 2018). Given that you cannot explain a variable with a constant, as the saying goes, we should probably ask, then, not what can be done to mitigate democracy's shorttermism, but what makes some democracies less prone to short-termism and more caring about the future than others. 
One way to approach this question is to separate out future-focused from futurebeneficial institutional setups (González-Ricoy and Gosseries, 2016b). Future-focused institutions, like specialized agencies and budgetary rules, have promoting intertemporally appropriate policies as their main purpose. Future-beneficial institutions, by contrast, do so as a byproduct of pursuing other goals. I will here zoom in on the former, which have dominated recent debates, especially among normative theorists (Tremmel, 2006; Thompson, 2010; Gardiner, 2014; Caney, 2016; Smith, 2019). But there is a growing literature on how institutions whose chief aim is not to promote farsighted policies, like proportional electoral rules (Lindvall, 2017; Finnegan, 2019), government transparency (Aguiar, et al., 2019), institutional capacity (Jacobs, 2011), and low corruption (Garri, 2010), crucially contribute to this end. Given that the diversity of sources of short-termism (see next section) invites a diversity of institutional responses, and that future-beneficial institutions may be easier to adopt, as they can be justified on independent grounds, one can only hope that research on future-beneficial institutions will further grow.

Future-focused institutions, on which the rest of the chapter will focus, seek to extend the temporal gaze of policymaking not as a side effect of pursuing other purposes but as their main or even sole purpose. They abound, comprising ombudspersons for future generations, foresight practices, youth quotas, budgetary rules, deliberative minipublics, intergenerational trust funds, climate banks, and parliamentary committees, to mention some. For tractability, I here inspect two types that have elicited much recent debate: insulating and constraining devices (Brunner, et al., 2012; Jacobs and Matthews, 2017; Boston, 2017: 186 ff.).

\subsection{Insulating devices}

Insulating devices aim at extending the temporal gaze of policy choices by shielding them from short-termist pressures. Commitment theorists, for example, have long argued that long-term policy commitments may be easier to adopt, harder to renege, and more credible if (some) policymaking authority is transferred away to bodies whose members are not elected by citizens, nor directed by elected officials, and thus less liable to electoral pressures (Majone, 1996). Similarly, some democratic theorists have argued that delegation to unelected bodies that are appointed by elected officials yet do not serve at their pleasure may avoid that policymaking be dominated by electoral motives (Pettit, 2012: ch. 4).

Depending on their authority, insulating devices can take the form of an agency or a watchdog (Brunner, et al., 2012). Agencies wield final authority to enact certain policies on the government's behalf (Thatcher and Stone Sweet, 2003). Independent central banks and constitutional courts are clear examples. But some have suggested that an energy agency tasked with meeting an emission target by, for example, setting a carbon tax could play an analogous role (Helm, et al., 2003).

Watchdogs, by contrast, are bodies whose authority is restricted to advising and monitoring the government on certain areas. Independent offices for future generations, 
such as those established in 2001 in Israel, in 2008 in Hungary, and in 2016 in Wales, are illustrative (Boston, 2017; Smith, 2019). They typically lack legislative or executive authority, though they may also wield some quasi-governing powers. For example, the Israeli Commissioner for Future Generations, which was discontinued after one term, had authority to delay legislation that could potentially harm future generations (Shoham and Lamay, 2006). And the Hungarian Commissioner for Future Generations, whose primary task was to safeguard the constitutional right to a healthy environment for future generations, could suspend administrative orders and seek action from the Constitutional Court until its status was downgraded in 2012.

This is just one possible way of insulating policymaking - one that seeks to do so by screening out those who, like elected officials, are deemed more prone to short-termism. Alternatively, policymaking may be insulated by screening in or upgrading the power of those who presumably are future-friendlier, as Dobson (1996) and Bidadanure (2016b) have suggested, respectively, as to members of environmental associations and to the youth. On Dobson's much-discussed proposal, seats in parliament are reserved for representatives of future generations, who are elected among and by environmental activists. On Bidadanure's proposal, youth quotas are introduced in parliament (see also van Parijs, 1998, and Karnein and Roser, 2015, for detailed discussion).

\subsection{Constraining devices}

Instead of transferring authority away from elected officials, as insulating devices do, constraining devices seek to bind elected officials to intergenerationally appropriate rules from which deviation is costly.

Constitutionalizing norms of intergenerational fairness, which many countries have done in recent decades, often coupled with requirements to foster sustainable development and with fiscal rules, is one means to this end (May and Daly, 2015; González-Ricoy and Rey, 2019). The basic idea is that constitutional provisions enjoy normative priority over ordinary statutes, can only be amended by means that are costlier than ordinary lawmaking procedures, like qualified majority requirements, and are often enforceable by courts, which may review legislative and administrative actions deviating from their content, as courts in the Philippines, Chile, and the Netherlands and have done in recent decades. ${ }^{2}$ So constitutionalization makes it harder for present and future incumbents to deviate from the provisions' content.

Budgetary rules, such as hypothecated taxes and trust funds, may perform a similar task at the statutory level (Patashnik, 2000; Brunner, et al. 2012). For they require that certain revenues be earmarked for a predeclared public policy purpose, like investing in

\footnotetext{
${ }^{2}$ See Supreme Court of the Philippines. Minors Oposa v. Secretary of the Department of Environment and Natural Resources (1991); Supreme Court of Chile. Comunidad de Chañaral v. Codelco División el Saldor (1997); Hague District Court. Urgenda Foundation v. The State of the Netherlands (2015); Hague Court of Appeal. The State of the Netherlands v. Urgenda Foundation (2018).
} 
early education or financing green technology. Given that their goals are also typically broken down into near-term targets that make deviations easy to detect, often provoking media and public outrage when they occur, they create strong incentives for elected officials not to deviate from their content.

We must finally note that, notwithstanding their disparities, neither insulating devices nor constraining devices seek to alter individuals' motivations, as alternative devices doexogenously, for example, through education (Zwarthoed, 2015), or endogenously, through deliberation (MacKenzie, 2018). Insulating and constraining devices, by contrast, do not aim to directly change individuals' motivations, though they may indirectly have this effect, as we will see below.

\section{Evaluative criteria}

Next consider two normative criteria to assess insulating and constraining devices: their effectiveness to cope with the various sources of wrongful short-termism and their legitimacy in allocating power, intra- and intergenerationally.

\subsection{Effectiveness}

The chief criterion to assess future-focused institutions is, of course, how effective they are at keeping wrongful short-termism at bay, and doing it with as low opportunity costs as possible and with the ability to remain in operation over time. We need to first know, then, what drives policymaking toward the short term. One way to approach this is to link the sources of short-termism to different types of political actors, like voters, politicians, special interest groups, and (the powerlessness of) future generations (MacKenzie, 2016). Another, which I here lean on, is to distinguish sources of short-termism according to whether they are of a motivational, epistemic, or institutional nature (González-Ricoy and Gosseries, 2016b; Boston, 2017).

Motivational determinants include voters' impatience and incumbents' desire to remain in office. Coupled with electoral competition, they offer a clear prediction of policy myopia. For, as noted above, if voters have a preference for immediate benefits, then incumbents seeking reelection have strong incentives to privilege policies yielding such benefits - "myopic policies for myopic voters," as Edward Tufte (1978: 143) noted. It is important to distinguish, however, pure time preference, which refers to a preference for immediate utility over delayed utility and is purely motivational, from time discounting, which refers to a preference for immediate consequences irrespective of the reason to value future consequences less, some of which may not be motivational (Frederick, et al., 2002). For example, Frederick (2003) finds that individuals' inclination to value future lives less than present lives largely results from uncertainty about whether future people will exist or whether long-term investments will benefit them, rather than from an intergenerational time 
preference. Once uncertainty is controlled for, individuals no longer value future generations less.

Epistemic determinants, on the other hand, include ignorance, various cognitive biases, and uncertainty. To illustrate, take climate policies. Voters and policymakers may discriminate against long-term benefits of mitigation policies, to start, if they ignore the harmful long-term effects that unabated climate change may yield. They may also do so if they happen to underestimate the likelihood of future disasters or to disdain abstract future harms whose victims are unidentifiable (Irving, 2009). And they may likewise do so if they are uncertain about who, and how many, will live in the future; about the world they will inhabit, including their technology to adapt to climate change; and about the likelihood of present policies yielding the promised long-term benefits, given the causal complexity involved (Jacobs and Matthews, 2017; van der Steen and van Twist, this volume).

Finally, consider institutional determinants. Suitably motivated and informed policymakers may still lack the institutional ability to produce long-term policy outcomes. For example, existing institutions may be too weak (Jacobs, 2011) or corrupt (Garri, 2010). And policymakers may also be liable to collective action problems (Gardiner, 2011; Brunner, et al., 2012: Goetz, 2014). These may be synchronic, such as when taking longterm climate action requires that other polities or private actors take it too, and a temptation to free ride on others' efforts exists. And they may be diachronic, such as when long-term action requires continued investment, which future incumbents need to uphold but may be tempted, for ideological or electoral reasons, to renege.

In addition, how effective future-focused institutions are, also hangs on their opportunity costs and on their ability to remain in operation over time. Opportunity costs comprise both foregone opportunities to invest in alternative institutions and, given that citizens' attention is scarce, cognitive opportunity costs. Three implications follow. First, though the causes of short-termism are diverse, such that tackling them will require a diversity of responses, there is always a cost in establishing a new institution. Parsimony matters. It also entails that if one institution (or cluster of institutions) is computationally less taxing than some alternative, then a pro tanto reason to adopt the former exists. It finally entails that institutions should not be assessed in isolation. We should also consider how a new device affects the existing institutional ecology, including its potential crowding out effects.

The ability to remain in operation over time is also important. For long-term investments often need to be sustained over long stretches of time, cutting across successive electoral cycles (Jacobs, 2011; Goetz, 2014; Caney, 2016). Further, given that sunk costs may be incurred when long-term investments are made, future-focused institutions that are easy to undo because their parliamentary support is fragile or can be discontinued by simple

majority, and whose prospects to remain in operation are small, may be less effective than establishing no such institution in the first place.

\subsection{Procedural legitimacy}


Consider now legitimacy criteria to assess future-focused institutions, which can be empirical and normative, substantive and procedural, and intra- and intergenerational. I here focus on normative and procedural criteria, both intra- and intergenerational.

Normative legitimacy has traditionally been conceived of as the right to rule, as the right that legitimate states have to issue and coercively enforce legal directives. What this view arguably entails is that institutions with no coercive authority, like merely advisory bodies, are largely immune to legitimacy assessments (Beckman and Uggla, 2016). But this is too narrow a view. Coercion surely sets the bar of legitimacy higher. Yet noncoercive institutions (think, for example, of a watchdog that acts ultra vires or grossly misuses public funds) are also liable to legitimacy concerns. What is at stake when we make legitimacy assessments is the broader issue of whether an institution merits our moral reason-based support (Adams, 2018; Buchanan, 2018).

Two clusters of conditions are relevant to assess whether future-focused institutions merit such support. Substantive conditions hang on their outcomes, and largely overlap with the effectiveness conditions discussed above. Procedural conditions, on which I here focus, hang on how such outcomes are brought about. They hang, in brief, on their ability to mitigate short-termism without infringing principles of procedural fairness-like those of political equality, democratic control, and sovereignty — in allocating power.

Intragenerationally applied, these principles are straightforward. They require that no individual or group be granted more power than other contemporaries to decide on the future. They also require that decision makers be authorized by and accountable to the relevant constituency. And they finally require that, in areas in which no duty toward future generations exists, because their interests are likely to be unaffected, such interests be ignored. For the opposite would amount to the subjection of present generations by future cohorts.

Intergenerationally applied, principles of procedural legitimacy are less clear. Take democratic control first. Though political institutions, to be legitimate, typically require authorization by and/or accountability to those whose interests are potentially affected, unborn generations and children below certain age are unable, for obvious reasons, to do this. But, just as safeguarding the interests of an unconscious patient could replace the need for informed consent to render a medical intervention legitimate, promoting future interests in policymaking, which is the very purpose of future-focused institutions, could replace the need for authorization and accountability to render such institutions legitimate (GonzálezRicoy and Gosseries, 2016b: 18). How fittingly they represent and safeguard such interests will crucially inform, then, how legitimate such institutions are. ${ }^{3}$

What political equality and sovereignty mean intergenerationally is also moot. A classic concern, which Jefferson and Condorcet already flagged, is that some institutions

\footnotetext{
${ }^{3}$ On how, and whether, future interests may be represented in present policymaking, see Karnein (2016), Lawrence and Köhler (2017), González-Ricoy and Rey (2019), and Campos (2020).
} 
unevenly allocate power across generations (Holmes, 1988; Otsuka, 2003; Gosseries, 2016). Constitutions in particular, whose content is hard to amend, could thwart future generations' ability to live under laws of their own choosing. Some, however, have resisted this idea by denying that extragenerational jurisdiction is possible. "Only the future can enforce the law of the future," Beckman (2013: 781) for example argues. "Thus, no law ever applies to the future unless affirmed by future people themselves."

One response is that, though enforcement across nonoverlapping generations is impossible, each generation will always have to agree with the rest in the overlap to amend the constitution. A two-thirds majority requirement, for example, will then make it hard for each single generation to amend the constitution. And, given that the shift from one overlap to the next is continuous, we are always in an overlap context (Gosseries, 2016: 105). Alternatively, we could accept that jurisdiction beyond the overlap is possible. Suppose that a simple majority of all generations alive at some point wished to amend the constitution without entirely replacing it. It would be contentious to say that a two-thirds majority requirement does not restrict their ability to do so (compared to the simple majority required by ordinary lawmaking) because they could pass the amendment by extraconstitutional means or by replacing the entire constitution. For this would amount to saying that an intrusive mother in law is innocuous because you could always get rid of her by divorcing your wife (whom you wish to stay married to). By the same token, in entrenching some laws against change, the founding generations can legally threaten subsequent generations' sovereignty because, in so doing, they can place the latter before this kind of tradeoffs.

\section{Assessing future-focused institutions}

We are now ready to discuss the effectiveness and legitimacy of insulating and constraining devices. I do not take up the gargantuan task of inspecting each and every criterion set out in the previous section for every instance of each device. Bearing in mind that institutional design is highly contingent on each country's institutional ecology, I rather discuss their main potential merits and weaknesses as to their effectiveness and legitimacy.

Before starting off, it is important to mention two important ways in which insulating and constraining devices may similarly contribute to keeping short-termist pressures at bay. First, both devices may overcome collective action problems by enabling credible commitment (Brunner, et al., 2012). Take climate change policy. By transferring some authority over climate policy to an office at arm's length from government, or by earmarking certain tax for investment in clean technology, for example, governments may credibly signal that they are "on board" with the long-term goal of reducing greenhouse gas emissions. In so doing, they may induce third parties, like companies and investors, to likewise reduce their emissions, on the assumption that it will be costly for present and future incumbents to renege this commitment and to free ride on their efforts (Helm, et al., 2003). 
Second, constraining and insulating devices may also importantly tackle citizens' short-termist motivations as well as their unawareness and cognitive biases by shaping public opinion. For example, by establishing independent offices for future generations, in particular if they have some bite, or by granting principles of intergenerational fairness constitutional status, governments can credibly signal to the public how important intergenerational matters are, inducing citizens to update their values and beliefs on such matters, as the literature on the expressive effects of the law suggests (e.g., McAdams, 2015).

It is also worth noting, before discussing legitimacy considerations, that there is no reason why the burden of proof should fall on future-focused institutions. Existing institutions are also liable to legitimacy concerns, as some of our present policies may importantly thwart future generations' interests, infringing our duties toward them (Dobson, 1996; O'Neill, 2001; Beckman, 2013). Future-focused institutions need justification no less than the status quo. Thus, in examining whether certain device merits our moral reason-based support, we must compare it not just to alternative devices (insulating, constraining, or otherwise) but also to existing institutions.

\subsection{Insulating devices}

Insulating devices are often seen as trading procedural legitimacy for effectiveness. In transferring authority away from officials that are liable to short-termist electoral pressures, they seem to aptly extend policy choices' temporal gaze. Yet this comes at a cost. For, in so doing, they appear to importantly deviate from principles of accountability and political equality. This picture, however, is simplistic. On closer inspection, numerous limitations as to their effectiveness arise. And steps may also be taken to mitigate some of the legitimacy problems they raise.

Start with effectiveness. Insulating devices aim, to repeat, at sheltering policymaking from short-termist pressures, such as electoral cycles. They do so by delegating authority to officials who are neither directly elected by the people, nor accountable to them, and can thus more easily avoid blame for risky, farsighted policy choices. This is true of delegation to independent agencies and watchdogs no less than of Dobson's proposal to reserve seats in parliament for representatives of future generations. For the latter would also be shielded from short-termist pressures from the electorate at large, as they would be elected among and by members of environmentalist associations, on the assumption that these are more aptly motivated than other citizens.

Yet, mere independence need not entail willingness to adopt more intertemporally balanced policies. Absent further conditions, like those related to the specific mandate that binds insulated officials, which we discuss below, why should we assume that they will be future-friendlier than elected ones? A plausible response is that independent bodies typically staff trained specialists, whose expertise exceeds that of elected officials, and that parliamentary representatives on Dobson's proposal would be elected among future- 
friendlier citizens. Expertise, however, says nothing about officials' particular goals. For example, the motivations and goals of central bankers (Adolph, 2013) and judges (Schauer, 1999), to name two cases of insulation from electoral pressures, seem not to be any less partisan than those of ordinary citizens. With regard to Dobson's proposal, on the other hand, one may ask why environmentalists should be assumed to be less prone to shorttermism than others, not just as to environmental lawmaking but also as to the range of areas on which members of parliament legislate. After all, other citizens may be active on other intertemporally relevant fronts, like education or poverty, out of concern for future generations (González-Ricoy and Gosseries, 2016b).

As to their ability to tackle the epistemic sources of short-termism, insulating devices yield mixed results. Expert input is no doubt crucial to tackle various epistemic determinants (Thatcher and Stone Sweet, 2002). It may, for example, increase public awareness of overlooked long-term issues. And it may likewise counter citizens' inclination to disdain future harms by offering reliable information and vivid examples, and yield better informed and less partisan policymaking on long-term issues. Insulation also allows for more flexibility than constraining devices to react to changing circumstances and to integrate new information about, for example, climate change damages or macroeconomic trends (Brunner, et al., 2012). Given that changes in circumstances and information are often likelier the longer the time horizon of the relevant policy choice and, thus, the more uncertainty involved (see, however, van Steen and van Twist, this volume), insulating devices are particularly well suited for policy choices whose effects extend over very long stretches of time.

Yet, when authority is transferred away to independent bodies, insulation may also increase, rather than mitigate, uncertainty about whether the desired long-term policy outcomes will arrive. For insulating certain policy choices from electoral pressures does little to constrain policymakers' room for maneuver. What is more, it also removes one potential tool to sanction them if they deviate from prior long-term commitments: the threat of electoral penalty. Indeed, in various survey experiments, Jacobs and Matthews (2017) find that insulating devices, unlike constraining devices, which we discuss below, yield no observable effect on support for long-term investments. For they do little to reduce the perceived political uncertainty about whether such investments will deliver the promised outcomes. Independent bodies, Jacobs and Matthews argue, place formidable computational demands on citizens, who typically ignore the motives of the officials that populate them and are thus reluctant to support them. This, in turn, raises concerns about the computational opportunity costs that such devices impose, given the demands to gather information about insulated officials' ends they impose on citizens, as well as about their ability to secure ample support.

Insulating devices encounter, thus, various hurdles to remain in operation over time, as the Israeli and the Hungarian offices for future generations, which lasted just one term before they were respectively discontinued and downgraded, can attest (Smith, 2019). One hurdle is, to repeat, citizens' hesitation to support institutions whose monitoring is 
informationally taxing. (Shoham and Lamay, 2006, also mention financial costs as one of the reasons why the Israeli office was suspended.) A second hurdle is that insulating devices are typically established by statute and can thus be easily discontinued. A third is that the primary constituency insulating devices seek to represent, minors and unborn generations, is powerless (Boston, 2017: 331). Some have argued, however, that embedding systematic participation from civil society associations in their operation may increase public support from present constituencies, rendering them less fragile if future incumbents attempt to discontinue them (Smith, 2019).

Next consider procedural legitimacy concerns, starting with intergenerational ones. Given that insulating devices are easy to discontinue by future cohorts, they cause little trouble from the standpoint of generational sovereignty. But the concerns about their effectiveness that we have just discussed translate, absent further details about their powers and mandate, into serious intergenerational legitimacy concerns. For, as discussed in the previous section, given that authorization by and accountability to future generations is not possible, the risk that insulated officials use their independence to advance interests other than those of future individuals, yielding long-term outcomes that fail to benefit or may even harm them, is very real.

In addition, given that insulated officials are neither authorized by nor accountable to present citizens, they are also liable to intragenerational concerns. Some have argued that, when insulating devices are established in response to political dysfunctionalities, like democracies' tendency to privilege the short term, and are subject to revocation by elected legislatures, they need not raise serious intragenerational legitimacy concerns (Pettit, 2012; Smith, 2019). Others are more skeptical. In the particular case of bodies whose purpose is to advance the interests of future people, there is a risk over and above the general legitimacy concern that nonelected institutions raise (Waldron, 1999). The risk, Karnein (2016: 87) argues, is that, absent authorization/accountability, insulated officials "may find speaking in the name of future generations a convenient and self-righteous way to avoid their duties to contemporaries, by putting the alleged interests of future generations first." They may, for example, deviate funds that could be profitably used for present purposes and whose diversion is harder to detect, given that their return is expected years or decades hence (Garri, 2010).

How serious legitimacy concerns stemming from the lack of authorization and accountability are, depends, however, on insulating devices' particular design. One aspect is the specific powers insulated officials are entrusted with, which can range from merely advising and monitoring governmental action to wielding full authority to enact policy. Another is the purview of such authority, which may encompass issues that are more or less politically contested and more or less technical. For example, courts have generally been reluctant to enforce constitutional norms of environmental safety, deferring action to legislatures instead, because, they have often argued, environmental decisions raise complex tradeoffs and have formidable distributive effects that elected institutions are more legitimate to assess (May and Daly, 2015). A third factor is the content of the mandate by 
which insulated officials are bound. For narrowly defined goals and means to pursue them, which a sufficientarian view of our intergenerational duties would recommend, alongside exacting monitoring mechanisms and parliamentary control over their budget and titular, may importantly reduce insulated officials' room for maneuver (Helm, et al., 2003; Brunner et al., 2012; González-Ricoy and Rey, 2019). And they may likewise reduce political uncertainty about long-term goals being delivered, hence mitigating intergenerational legitimacy concerns.

Note, however, that many of these factors plot, as it were, against the very rationale behind insulating devices. If, for example, we submit insulated officials to a tight mandate and exacting monitoring by elected officials, we then also reduce their flexibility to cope with changing information and their immunity from electoral pressures. Also note that, though these factors may importantly mitigate legitimacy concerns, absent citizens' authorization and accountability, such concerns are unlikely to entirely go away. Finally, note that these concerns are particularly intractable as to Dobson's proposal. For one thing, given that parliamentary representatives of future generations would have open-ended lawmaking authority, no mandate of the above kind could mitigate concerns about their effectiveness and intergenerational legitimacy. For another, given that they would be elected by and solely accountable to other environmentalists, excluding other citizens, the intragenerational legitimacy concerns the proposal raises are probably insurmountable.

\subsection{Constraining devices}

Constraining devices elude some of the hurdles insulating devices face as to their effectiveness and legitimacy. But they encounter new ones, which I here discuss.

Take motivational sources of short-termism first. Instead of delegating authority to nonelected officials, as insulating devices do, constraining devices seek to bind elected officials to intergenerationally apt rules from which deviation is costly. In so doing, they avoid leaning on a dubious inference from independence from electoral pressures to willingness to adopt intergenerationally fairer policies. Means to motivate officials to abide by such rules can take two forms. When granted constitutional status, rules enjoy normative priority over ordinary statutes, can only be amended by cumbersome means, and are often enforceable by courts, which may review, and sometimes revoke, statutes and administrative actions deviating from the rules' content. Elected officials have reason, then, to comply with the rules, lest their actions be rendered unconstitutional by a court and accordingly turned down, and cannot easily change them.

When constraining rules are adopted as statutory laws, none of these means are available. Given that they lack normative priority, that they can be changed by simple majority, and that they cannot be enforced through judicial review, some doubt whether they can have much effect on elected officials' opportunistic or electoral temptations. But much depends on how they are designed. If long-term rules are clear, as when they require that certain revenue be earmarked for some predefined purpose, and are broken down into 
near-term targets, then deviation may be easy to detect, triggering media outrage and loss of public support when it occurs (Patashnik, 2000; Jacobs and Matthews, 2017). If, in addition, they are designed to benefit present cohorts by, for example, reserving the proceeds of emission trading for redistribution to the poorest households, then public longterm support is likely to increase, and so they are the costs of diversion (Brunner, et al., 2012).

How effectively constraining devices address the epistemic sources of short-termism also importantly hinges on their design. On the one hand, in setting out clear rules and shielding them from officials' discretion, constraining devices are better equipped than insulating devices to mitigate uncertainty about whether the promised long-term payoffs will arrive (Jacobs and Matthews, 2017). On the other, however, they are also less flexible to cope with new information, which may result in less effective policies. Making rules easier to adapt to new conditions would create loopholes for opportunistic deviations, and attempting to foresee all future contingencies would be just impossible. But, serious though this problem is in areas that are liable to severe uncertainty and to recurrent information updates, like climate change abatement, certainty and flexibility need not be irreconcilable. For constraining rules may be adjusted to context-dependent factors whose content does not depend on governments. For example, rules setting the price or permissible quantity of greenhouse gas emissions may be able to adapt to new circumstances without creating loopholes for opportunistic deviation, Brunner at al. (2012) argue, if we make them contingent on predefined parameters, like new insights in climate science or international climate agreements, that are independent from elected officials and hard to manipulate.

Constraining devices' ability to address political sources of short-termism, on the other hand, crucially depends on their prospects to remain in operation over time. For whether they successfully contribute to overcoming synchronic collective action problems, inducing public and private agents to coordinate around the long-term goals set by a new rule, importantly depends on whether such agents expect that the rule will not be easily changed or ignored by future incumbents. This, in turn, depends both on their legal status and their design. Constitutional rules are typically hard to amend, whereas simple majorities are often enough to change statutory law. But, as we have seen, various factors can render the latter more resilient to change. First, statutory rules may generate long-term public support if they are designed to benefit not just future constituencies but also present ones. They may also be harder to undo if they are designed to make officials' attempts to change them easy to detect, as hypothecated taxes and trust funds aptly do. And, insofar as they make the outcomes of long-term investments less uncertain, they may likewise increase their public support, as Jacobs and Matthews (2017) argue.

Finally, consider legitimacy concerns. Insofar as constraining devices are selfimposed by parliaments, they raise few intragenerational difficulties. When they are granted constitutional status, however, they raise a well-known intergenerational concern (Otsuka, 2003; Gosseries, 2016; Tremmel, 2019). Given that future generations will have a hard time amending their content should they want to do so, constitutionalizing 
constraining rules may end up imposing the will of the founding generations on subsequent ones, threatening the ability of the latter to live under laws of their own choosing. Briefly consider some responses to this concern (for more detailed discussion, see González-Ricoy, 2016). One is that the concern only arises when constitutional norms seek to track and safeguard future preferences. Given that these are likely to evolve over time and across cohorts, the norms' content, albeit well-intended, may end up unfittingly reflecting them. The concern largely disappears, on this view, when constitutional rules are limited to safeguarding future people's basic needs, which are unlikely to change over time, as constraining devices on a sufficientarian view seek to do (Ekeli, 2007).

In addition, how constraining devices are formulated and adopted may also mitigate the generational sovereignty concern. First, if constitutional provisions, unlike statutory rules, are formulated abstractly, as general principles rather than specific rules, future cohorts may be able to adjust their understanding to fit an evolving society, as generational change occurs and circumstances vary (Ferreres, 2000; Waluchow, 2007). Second, if the relevant provisions are adopted under conditions that are normatively more demanding than ordinary lawmaking conditions_-if, say, they are adopted after a process of consultation and deliberation among parties, associations, and citizens and they reach ample, bipartisan support — difficulty to amend them may safeguard, rather than constrain, citizens' will from the risk that elected officials may easily renege them (Ackerman, 1991). Although none of these responses is likely to make the intergenerational concern entirely go away, for future generations would be unable to easily amend the rules all the same, they may importantly mitigate it.

\section{Conclusion}

Normative theorists and social scientists studying intergenerational politics have profitably teamed up in recent years. They have inspected, among other things, our duties toward future generations, the drivers of political short-termism that hinder that such duties be discharged in public policymaking, and the conditions to render institutional responses to short-termism effective and legitimate. This chapter has surveyed recent normative research on these issues, focusing on two prominent responses: insulating and constraining devices.

For all their virtues, however, these responses are no panacea. One reason is that, given that both our duties toward future generations and the sources of short-termism are diverse and vary across policy choices, a diverse mix of responses is needed. Another is that institutions that promote intertemporally fair policies not as their primary goal, as insulating and constraining devices do, but as a byproduct of pursuing other goals, like electoral rules or government transparency do, may also be critical to achieving this end, as

growing research suggests. A third reason is that both the particular design and the viability of these and similar responses importantly hinges on each country's institutional ecology. Further work linking normative theorizing and empirical research on these matters is, thus, badly needed. 


\section{References}

Ackerman, Bruce. 1991. We the People. Foundations. Cambridge, MA: Harvard University Press.

Adams, Nathan P. 2018. "Institutional legitimacy." Journal of Political Philosophy 26, no. 1: 84-102.

Adolph, Christopher. 2013. Bankers, bureaucrats, and central bank politics: The myth of neutrality. Cambridge: Cambridge University Press.

Aguiar-Conraria, Luís, Pedro C. Magalhães, and Francisco J. Veiga. 2019. "Transparency, Policy Outcomes, and Incumbent Support." Kyklos 72, no. 3: 357-380.

Beckman, Ludvig. 2013. "Democracy and Future Generations. Should the Unborn Have a Voice?" In Spheres of Justice - Vol. 2, edited by Jean-Christophe Merle, 775-788. Dordrecht: Springer.

Beckman, Ludvig, and Fredrick Uggla. 2016. "An Ombudsman for Future Generations." In Institutions For Future Generations, edited by Iñigo González-Ricoy and Axel Gosseries, 117-134. Oxford: Oxford University Press.

Bidadanure, Juliana. 2016a. "Making sense of age-group justice: A time for relational equality?" Politics, Philosophy and Economics 15, no. 3: 234-260.

Bidadanure, Juliana. 2016b. "Youth Quotas, Diversity, and Long-Termism. In Institutions For Future Generations, edited by Iñigo González-Ricoy and Axel Gosseries, 266-281. Oxford: Oxford University Press.

Boston, Jonathan. 2017. Governing for the Future: Designing Democratic Institutions for a Better Tomorrow. Bingley: Emerald.

Broome, John. 1994. "Discounting the Future." Philosophy and Public Affairs 23, no. 2: $128-156$.

Brunner, Steffen, Christian Flachsland, and Robert Marschinski. 2012. "Credible commitment in carbon policy." Climate Policy 12, no. 2: 255-271.

Buchanan, Allen. 2018. "Institutional Legitimacy." Oxford Studies in Political Philosophy 4: 53-80.

Campos, Andre Santos. 2020. "Representing the future: The interests of future persons in representative democracy." British Journal of Political Science. doi:10.1017/S000712341900067X.

Caney, Simon. 2016. "Political Institutions for the Future: A Five-Fold Package." In Institutions For Future Generations, edited by Iñigo González-Ricoy and Axel Gosseries. Oxford: Oxford University Press.

Caney, Simon. 2018. "Justice and Future Generations." Annual Review of Political Science 21: 475-493.

Caney, Simon. 2019. Democratic Reform, Intergenerational Justice and the Challenges of the Long-Term. Centre for the Understanding of Sustainable Prosperity. 
Casal, Paula. 2007. "Why Sufficiency Is Not Enough,” Ethics 117, no. 2: 296-326.

Casal. Paula, 2019. "Conservative and Conservationist Sufficiency." Paper presented at the Future Generations and Political Action workshop, University of Barcelona.

Dobson, Andrew. 1996. "Representative Democracy and the Environment." In Democracy and the environment: Problems and prospects, edited by William M. Lafferty and James Meadowcroft, 124-139. Cheltenham: Edward Elgar.

Ekeli, Kristian S. 2007. "Green Constitutionalism: The Constitutional Protection of Future Generations.” Ratio Juris 20, no. 3: 378-401.

Expansión. 2015. "Alvaro Nadal apuesta por controlar costes e inversión en I+D para ser más competitivos a corto plazo". http://www.expansion.com/agencia/europa press/2015/03/23/20150323130525.html.

Ferreres, Víctor. 2000. “A Defense of Constitutional Rigidity.” Analisi e Diritto: 45-68.

Finnegan, Jared J. 2019. Institutions, climate change, and the foundations of long-term policymaking. Grantham Research Institute on Climate Change and the Environment working paper.

Fleurbaey, Marc. 2015. "Equality versus priority: how relevant is the distinction?" Economics and Philosophy 31, no. 2: 203-217.

Frederick, Shane. 2003. "Measuring intergenerational time preference: Are future lives valued less?" Journal of Risk and Uncertainty 26, no. 1: 39-53.

Frederick, Shane, George Loewenstein, and Ted O'Donoghue. 2002. "Time Discounting and Time Preference: A Critical Review." Journal of Economic Literature 40, no. 2: $351-401$.

Gallery, Gerry and Natalie Gallery. 2009. "Short-termism: challenges and resolutions." Australian Accounting Review 19, no. 4: 275-277.

Gardiner, Stephen. 2011. A perfect moral storm: The ethical tragedy of climate change. Oxford: Oxford University Press.

Gardiner, Stephen. 2014. "A Call for a Global Constitutional Convention Focused on Future Generations." Ethics and International Affairs 28, no. 3: 299-315.

Garri, Iconio. 2010. "Political Short-Termism: A Possible Explanation." Public Choice 145, no. 1-2: 197-211.

Goetz, Klaus H. 2014. "A question of time: responsive and responsible democratic politics." West European Politics 37, no. 2: 379-399.

González-Ricoy, Iñigo. $2016 . \quad$ "Legitimate Intergenerational Constitutionalism." Intergenerational Justice Review 2, no. 2: 40-48.

González-Ricoy, Iñigo, and Axel Gosseries, eds. 2016a. Institutions for Future Generations. Oxford: Oxford University Press.

González-Ricoy, Iñigo, and Axel Gosseries. 2016b. "Designing institutions for future generations: An introduction." In Institutions For Future Generations, edited by Iñigo González-Ricoy and Axel Gosseries, 3-23. Oxford: Oxford University Press. 
González-Ricoy, Inigo, and Felipe Rey. 2019. "Enfranchising the future: Climate justice and the representation of future generations." Wiley Interdisciplinary Reviews: Climate Change 10, no. 5: e598.

Gosseries, Axel. 2016. "Generational sovereignty." In Institutions For Future Generations, edited by Iñigo González-Ricoy and Axel Gosseries, 98-116. Oxford: Oxford University Press.

Gosseries, Axel. 2017. "Intergenerational justice, sufficiency, and health." In What is enough? Sufficiency, justice, and health, edited by Carina Fourie and Annette Rid. Oxford: Oxford University Press.

Heckman, James J., Seong Hyeok Moon, Rodrigo Pinto, Peter A. Savelyev, and Adam Yavitz. 2010. "The rate of return to the High Scope Perry Preschool Program." Journal of public Economics 94, no. 1-2: 114-128.

Helm, Dieter, Cameron Hepburn, and Richard Mash. 2003. "Credible carbon policy." Oxford Review of Economic Policy 19, no. 3: 438-450.

Holmes, Stephen. 1988. "Precommitment and the Paradox of Democracy." In Constitutionalism and democracy, edited by Jon Elster, Rune Slagstad, and Gudmund Hernes. Cambridge: Cambridge University Press.

Irving, Kym. 2009. "Overcoming Short-Termism." Australian Accounting Review 19, no. 4: 278-294.

Jacobs, Alan M. 2011. Governing for the long term: democracy and the politics of investment. Cambridge: Cambridge University Press.

Jacobs, Alan M., and J. Scott Matthews. 2017. "Policy attitudes in institutional context: Rules, uncertainty, and the mass politics of public investment." American Journal of Political Science 61, no. 1: 194-207.

Karnein, Anja. 2016. "Can we Represent Future Generations?" In Institutions For Future Generations, edited by Iñigo González-Ricoy and Axel Gosseries, 83-97. Oxford: Oxford University Press.

Karnein, Anja, and Dominic Roser. 2015. "Saving the planet by empowering the young?" In Youth quotas and other efficient forms of youth participation in ageing societies, edited by Jörg Tremmel, Antony Mason, and Petter Godli, 77-92. Cham: Springer.

Katz, Corey. 2017. "Neorepublicanism and the Domination of Posterity." Ethics, Policy \& Environment 20, no. 3: 294-313.

Kumar, Rahul, 2018. "Future Generations." In The Oxford Handbook of distributive justice, edited by Serena Olsaretti, 689-710. Oxford: Oxford University Press.

Lawrence, Peter, and Lukas Köhler. 2017. "Representation of Future Generations through International Climate Litigation: A Normative Framework." German Yearbook of International Law 60: 1-29.

Liberto, Hallie. 2014. "The exploitation solution to the Non-Identity Problem." Philosophical Studies 167, no. 1: 73-88.

Lindvall, Johannes. 2017. Reform capacity. Oxford: Oxford University Press. 
MacKenzie, Michael, 2016. "Institutional design and sources of short-termism." In Institutions For Future Generations, edited by Iñigo González-Ricoy and Axel Gosseries, 24-48. Oxford: Oxford University Press.

MacKenzie, Michael. 2018. "Deliberation and Long-Term Decisions." In The Oxford handbook of deliberative democracy, edited by Andre Bächtiger, John S. Dryzek, Jane Mansbridge, and Mark Warren, 251-273. Oxford: Oxford University Press.

Majone, Giandomenico. 1996. Temporal Consistency and Policy Credibility: Why Democracies Need Non-Majoritarian Institutions. European University Institute Working Paper ESC 96/57.

May, James R., and Erin Daly. 2015. Global environmental constitutionalism. New York: Cambridge University Press.

McAdams, Richard H. 2015. The Expressive Powers of Law. Cambridge, MA: Harvard University Press.

Meijers, Tim. 2018. "Justice Between Generations." Oxford Research Encyclopedia of Politics. Oxford: Oxford University Press.

Meyer, Lukas, and Dominic Roser. 2009. "Enough for the Future." In Intergenerational Justice, edited by Axel Gosseries and Lukas Meyer, 219-248. Oxford: Oxford University Press.

Mulgan, Tim. 2006. Future Persons: A Moderate Consequentialist Account of our Obligations to Future Generations. Oxford: Clarendon Press.

Nordhaus, William. 1975. "The Political Business cycle." The Review of Economic Studies 42, no. 2: 169-190.

Nordhaus, William. 2008. A Question of Balance: Economic Modeling of Global Warming. New Haven, CT: Yale University Press.

O'Neill, John. 2001. "Representing people, representing nature, representing the world." Environment and Planning C: Government and Policy 19, no. 4: 483-500.

Otsuka, Michael. 2003. Libertarianism Without Inequality. Oxford: Clarendon Press.

Oxford Martin Commission for Future Generations. 2013. Now for the long term: The report of the Oxford Martin Commission for future generations. Oxford: University of Oxford.

Parfit, Derek. 1997. "Equality and Priority." Ratio 10, no. 3: 202-221.

Patashnik, Eric M. 2000. Putting trust in the US budget: Federal trust funds and the politics of commitment. Cambridge: Cambridge University Press.

Pettit, Philip. 2012. On the People's Terms: A Republican Theory and Model of Democracy. Cambridge: Cambridge University Press.

Price, Colin. 2003. "Diminishing Marginal Utility: The Respectable Case for Discounting?" International Journal of Sustainable Development 6, no. 1: 117-132.

Rawls, John. 1999. A Theory of Justice. Revised ed. Cambridge, MA: Harvard University Press.

Schauer, Frederick. 1999. "Incentives, reputation, and the inglorious determinants of judicial behavior." University of Cincinnati Law Review 68: 615. 
Shoham, Shlomo, and Nira Lamay. 2006. "Commission for Future Generations in the Knesset: lessons learnt," Handbook of intergenerational justice, edited by Jörg Tremmel, 244-281. Cheltenham: Edward Elgar.

Smith, Graham. 2019. "Enhancing the legitimacy of offices for future generations: the case for public participation.” Political Studies. doi:0032321719885100.

Thatcher, Mark, and Alec Stone Sweet. 2002. "Theory and Practice of Delegation to NonMajoritarian Institutions." West European Politics 25, no. 1: 1-22.

Thompson, Dennis F. 2010. "Representing future generations: political presentism and democratic trusteeship." Critical review of international social and political philosophy 13, no. 1: 17-37.

Tremmel, Jörg. 2019. "Whose Constitution? Constitutional Self-Determination and Generational Change." Ratio Juris 32, no. 1: 49-75.

Tremmel, Jörg, ed. 2006. Handbook of intergenerational justice. Cheltenham: Edward Elgar.

Tufte, Edward R. 1978. Political Control of the Economy. Princeton, NJ: Princeton University Press.

United Nations Secretary-General. 2013. Intergenerational Solidarity and the Needs of Future Generations. New York: United Nations Secretary-General.

Van Parijs, Philippe. 1998. "The Disfranchisement of the Elderly, and Other Attempts to Secure Intergenerational Justice." Philosophy \& Public Affairs 27, no. 4: 292-333.

Waldron, Jeremy. 1999. Law and disagreement. Oxford: Oxford University Press.

Wil, Waluchow. 2007. A Common Law Theory of Judicial Review: The Living Tree. Cambridge: Cambridge University Press.

World Commission on Environment and Development. 1987. Our Common Future. Oxford: Oxford University Press.

Zwarthoed, Danielle. 2015. "Creating Frugal Citizens: The Liberal Egalitarian Case for Teaching Frugality." Theory and Research in Education 13, no.3: 286-307. 